A Journal of Culture, English Language, Teaching \& Literature

ISSN 14143320 (Print), ISSN 2502-4914 (Online)

Vol. 17 No. 2; December 2017

Copyright (C) Soegijapranata Catholic University, Indonesia

Developing English Job Interview Skill by Self-Access Language Learning of Audio Podcast-Based Learning Media

${ }^{1}$ Aloysius Soerjowardhana, ${ }^{2}$ Raden Arief Nugroho

English Department, Faculty of Humanities, Universitas Dian Nuswantoro, Semarang, Indonesia

email: 12donyswardhana18@gmail.com; 2arief.nugroho@dsn.dinus.ac.id

Received: 29-10-2017 Accepted: 2-11-2017 Published: 05-12-2017 


\title{
Developing English Job Interview Skill by Self-Access Language Learning through Audio Podcast-Based Learning Media
}

\author{
${ }^{1}$ Aloysius Soerjowardhana and ${ }^{2}$ Raden Arief Nugroho \\ 1donyswardhana18@gmail.com; ${ }^{2}$ arief.nugroho@dsn.dinus.ac.id \\ 1,2English Department, Faculty of Humanities, Universitas \\ Dian Nuswantoro, Semarang, Indonesia
}

\begin{abstract}
In the era of ASEAN Economic Community (AEC), Indonesian job seekers must have English competency. Without mastering English language, they will be defeated by foreign readyto-use job seekers. It can be detected in the job interview that their English competency is low. It is caused by a serious condition that they have no effective time to learn English in formal or nonformal English schools. Hence, an effort to improve their English speaking skill is needed. One of the ways to improve English speaking skill is by Self-Access Language Learning (SALL) through audio podcast-based learning media. By using audio podcast-based learning media, the job seekers can practice their English speaking ability by themselves anytime and anywhere. This research conducted an action research to investigate the improvement of English job interview skill of an interviewee with intermediate level of English, which was focused on the improvement of the interviewee abilities to answer the interviewer's questions. To assess the quality of the English job interview, the researchers used an interview quality parameter designed by Overseas Programming and Training Support (OPATS) Peace Corps (2005). It is based on the assessment of function and content. The result shows that after two treatments, the job seeker (interviewee) improves her English job interview skill. The improvement can be seen from the changes according to the functional ability; it is shown from the change of answer style from descriptive into narrative way and the changes according to the content; it is shown from the change of answer content from daily routine into professional rational. Therefore, the researchers recommend the Indonesian job seekers to use audio podcast-based learning media by SALL to develop their English job interview skill.
\end{abstract}


Soerjowardhana, A. \& Nugroho, R.A., Developing English Job Interview Skill 179 by SALL through Audio Podcast Based Learning Media

Key words: audio podcast, English job interview, Self-Access Language Learning (SALL)

Abstrak: Di era Masyarakat Ekonomi ASEAN (MEA), pencari kerja Indonesia harus memiliki kompetensi bahasa Inggris. Tanpa kompetensi tersebut, pencari kerja Indonesia akan kalah bersaing dengan pencari kerja asing yang memiliki kemampuan berbahasa Inggris. Dari pengamatan di berbagai wawancara kerja, penulis dapat mengidentifikasi bahwa kemampuan bahasa Inggris pencari kerja Indonesia rendah. Hal tersebut disebabkan karena mereka tidak memiliki waktu belajar bahasa Inggris yang efektif di sekolah formal atau nonformal. Oleh sebab itu, sebuah cara dibutuhkan agar kemampuan wawancara kerja bahasa Inggris mereka meningkat. Salah satunya dengan menggunakan metode pembelajaran Self-Access Language Learning (SALL) berbasis audio podcast. Melalui cara tersebut, pencari kerja Indonesia dapat berlatih meningkatkan kemampuan wawancara bahasa Inggrisnya di mana pun dan kapan pun. Penelitian ini merupakan penelitian tindakan (action research) yang bertujuan untuk mengidentifikasi peningkatan kemampuan wawancara kerja bahasa Inggris dari seorang pencari kerja dengan atribut kemampuan bahasa Inggris tingkat menengah. Penelitian ini difokuskan pada peningkatan cara menjawab dan konten jawaban pencari kerja Indonesia di sebuah wawancara kerja bahasa Inggris. Untuk menilai kualitas jawaban wawancara kerja, para peneliti menggunakan parameter kualitas wawancara yang dikembangkan oleh Overseas Programming and Training Support (OPATS) Peace Corps (2005). Penilaian itu berdasarkan pada aspek fungsi dan konten. Hasil dari penelitian ini menunjukkan bahwa pencari kerja Indonesia mampu meningkatkan jawaban dari wawancara kerja bahasa Inggrisnya. Peningkatannya dapat dilihat dari segi: 1) perubahan aspek fungsi yang terlihat dari pergeseran pola jawab dari deskriptif menjadi naratif; dan 2) perubahan aspek konten yang terlihat dari pergeseran konten jawaban dari sesuatu yang bersifat rutinitas menjadi sesuatu yang bersifat profesional. Dengan demikian, para peneliti merekomendasikan para pencari kerja Indonesia lainnya untuk menggunakan metode pembelajaran Self-Access Language Learning (SALL) berbasis audio podcast untuk meningkatkan kemampuan wawancara kerja bahasa Inggrisnya.

Kata kunci: audio podcast, Self-Access Language Learning (SALL), wawancara kerja bahasa Inggris 
180 Celt: A Journal of Culture, English Language Teaching \& Literature, Volume 17, Number 2, December 2017, pp. 178 - 195

\section{INTRODUCTION}

To get success in a job interview, a job seeker should master the job interview skill. He needs to improve his speaking skill more than the other three language skills such as listening, reading and writing. Mastering English is very important for an Indonesian job seeker who wants to get a job in a foreign or multinational company. Most of the foreign or multinational company requires job interviews in English. Indonesian job seekers who do not master English language will definitely be defeated by foreign ready-to use job seekers. To improve their English language skills, especially speaking, they need to learn and practice a lot. One of some ways to improve English speaking skill is by selfaccess language learning through audio podcast-based learning media. By using audio podcast-based learning media, the job seekers can practice their English speaking ability by themselves anytime and anywhere. Online media world offers many programs which can be downloaded and one of them is the audio podcast. This issue has encouraged the researcher to conduct a research entitled "Developing English Job Interview Skill by Self-Access Language Learning through Audio Podcast-Based Learning Media".

\section{LITERATURE REVIEW}

\section{A. Self-Assess Language Learning (SALL)}

Self-Access Language Learning (SALL) is a learning method which emphasizes self- learning or autonomous learning (autonomy). It requires Autonomy, Learning, and Dependence (Diaz, 2010, p. 45). In this case, the adult learners, especially job seekers, can be called as autonomous learners because they prefer to learn by themselves instead of being instructed. They tend to not having much time to study because they are busy with their daily activities. By autonomous learning, they can identify their weaknesses which are needed to improve or correct. Some benefits offered by SALL refer to the usage of learning technology which can be used by the learners independently because of its time and space flexibility (Diaz, 2010, p.32).

\section{B. Audio podcast}

According to Merriam-Webster Dictionary ("podcast," n.d.) "a podcast is an episodic series of digital audio files which a user can download and listen to. It is often available for subscription so that new episodes are automatically downloaded via web syndication to the user's own local computer, mobile 
Soerjowardhana, A. \& Nugroho, R.A., Developing English Job Interview Skill 181 by SALL through Audio Podcast Based Learning Media

application, or portable media player". Audio podcast has more benefits than video podcast since it can be operated without using vision sense. It means that audio podcast can be used while doing another activity such as driving car or cooking. So a blind person can also get positive benefit by using this audio podcast compare to video podcast.

\section{METHODOLOGY}

\section{A. Research design}

The primary objective of this study was to investigate the improvement of English job interview skill of an interviewee with an intermediate level of English. The objective could only be accomplished through action research involving action and reflection. According to McDonough (in Varasarin, 2007, p.50) "the initial conception of action research emphasized its potential to empower and emancipate participants through cycles of reform based on reflection and action". The study was conducted in two cycles in which each cycle had four steps: plan, act, observe, and reflect (Kemmis and McTaggart, 1988). The cycles of the study are illustrated as follows:

Figure 1:

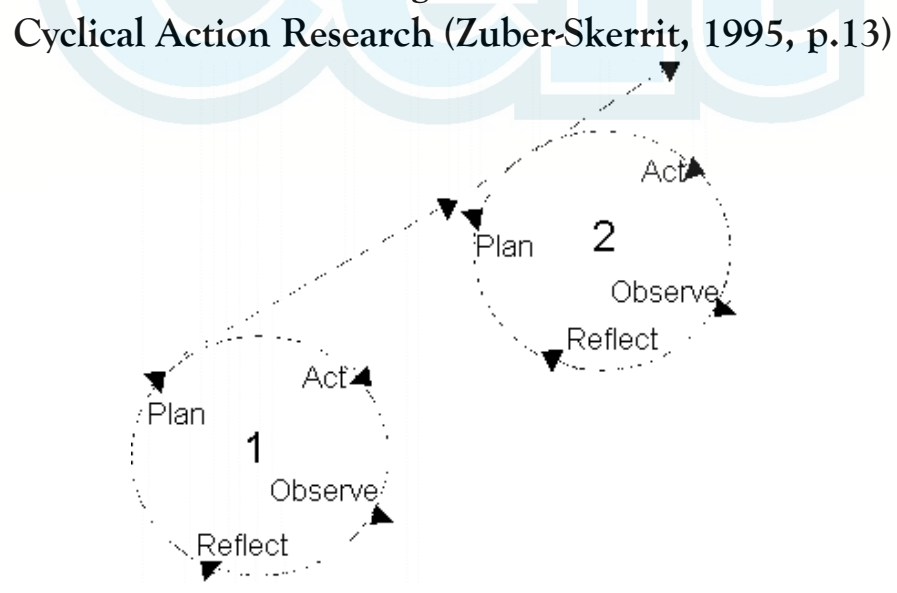

Firstly, plan step was done to identify what difficulties dealt by the interviewee in English job interview situation and what possible improvement could be made possible to solve the difficulties. Next, act step dealt with the implementation of plan step to learning situation. During learning situation, the subject of research was asked to perform SALL through audio podcastbased learning media. Then, observe step was conducted by the researchers to observe and record all activities happened and outcomes of the action during 
182 Celt: A Journal of Culture, English Language Teaching \& Literature, Volume 17, Number 2, December 2017, pp. 178 - 195

the research. Lastly, reflect step coped with the evaluation and reflection toward the effects of action step. This last step was utilized in order to create improvements in the next cycle.

\section{B. Research subject and site}

There was one research subject in this study. The research subject involved was a job seeker who recently graduated from the English Department of Universitas Dian Nuswantoro, Semarang. She was a graduate with intermediate level of English. It was proven from her 542 TOEFL score. The researchers identified that 542 TOEFL score was categorized into threshold (intermediate) level (www.ets.org). The research took place at Dinus Career Center (DCC) where students or alumni of Universitas Dian Nuswantoro can improve their professional skills required in the job field and to find information about job opportunities. In this study, the research subject was asked to learn English job interview (structured conversation) with SALL through audio-podcast based learning media for four weeks (two learning cycles).

\section{Data collection}

The data collection of this study was composed of two instruments, namely oral test and observation sheet.

\section{Oral test}

Oral test was used to measure the progress of research subject's English job interview skill. It was conducted in the end of each cycle after SALL through audio-podcast based learning media was being conducted. The test was recorded with audio recorder and its result was transcribed. The research subject answered interviewer's questions pertaining to five interview topics; namely personality assessment, professional motivation, career development, working experience, and knowledge about the employer.

\section{Observation sheet}

The observation was carried out during the realization of action research. It was used to gain data concerning the learning process of English job interview skill using SALL through audio-podcast based learning media. The researchers acted as observers and they conducted the observation by completing the observation sheet and taking observation notes required for reflect step. 
Soerjowardhana, A. \& Nugroho, R.A., Developing English Job Interview Skill 183 by SALL through Audio Podcast Based Learning Media

\section{Data analysis}

All qualitative data were gathered from the oral test and observation sheet. From the aforementioned instruments, the researchers analyzed the linguistic pattern of research subject's English job interview. To assess its quality, the researchers used an interview quality parameter designed by Overseas Programming and Training Support (OPATS) Peace Corps (2005). It was based on the assessment of function aspects below:

Table 1:

Function (Overseas Programming and Training Support (OPATS) Peace Corps, 2005, p.34)

\begin{tabular}{ll}
\hline Level & Description \\
\hline \hline Superior & Handles abstract topics and situations, support opinions, hypothesizes \\
\hline Advanced & $\begin{array}{l}\text { Can get into, through and out of situations with a complication, } \\
\text { narrates, describes, explains, compares, and discusses in past, present, } \\
\text { and future time/major aspect frames }\end{array}$ \\
\hline Intermediate & $\begin{array}{l}\text { Creates with language and maintains simple conversations, asks and } \\
\text { answers questions, can get into, through and out of simple social } \\
\text { and/or transactional situations }\end{array}$ \\
\hline Novice & $\begin{array}{l}\text { Produces formulaic utterances and lists, but shows no functional } \\
\text { ability }\end{array}$ \\
\hline
\end{tabular}

The assessment based on the content adheres with the aspects like shown in Table 2.

Table 2:

Content (Overseas Programming and Training Support (OPATS) Peace Corps, 2005, p. 34)

\begin{tabular}{ll}
\hline Level & Description \\
\hline \hline Superior & $\begin{array}{l}\text { 1. Expression and defense of opinions about current events and } \\
\text { other topics }\end{array}$ \\
& $\begin{array}{l}\text { 2. Practical, social, professional, and abstract topics } \\
\text { 3. Particular interests and special field of competence }\end{array}$ \\
\hline Advanced & $\begin{array}{l}\text { Concrete topics going beyond self and community, family, extending } \\
\text { to work, community, and current events }\end{array}$ \\
\hline Intermediate & $\begin{array}{l}\text { 1. Everyday topics, such as self, home, family, interests, and leisure or } \\
\text { recreation }\end{array}$ \\
\hline
\end{tabular}


184 Celt: A Journal of Culture, English Language Teaching \& Literature, Volume 17, Number 2, December 2017, pp. 178 - 195

2. Daily routine, familiar surroundings

3. Routine travel needs

Novice

Minimum courtesy requirements and high frequency, formulaic, mostly memorized expressions, basic objects, months, body parts, numbers, situations, colors, time, clothing, weather, date, weekdays, family members, year, foods

Based on these parameters, the researchers analyzed and compared the linguistic pattern occurred in the first and second cycles. Here, the researchers marked any discrete function and content parameters and concluded the relationship of SALL through audio-podcast based learning media and improvement of English job interview skill.

\section{E. Research procedure}

In implementing Action Research (AR) in this study, the researchers employed two cycles in which each cycle consisted of eight 45 minute meetings lasted in two weeks. AR involved four stages including planning, acting, observing, and reflecting described as follows:

1. Planning

Time: Cycle $1 \& 2$ : Meeting 1 and 2

Description: It was planned prior to acting stage. After finding out research subject's English job interview skill problems, important items were then prepared, such as a SALL-based learning instruction for the subject of research, audio-podcast, and observation sheet.

2. Acting

Time: Cycle $1 \& 2$ : Meeting 3, 4, 5, 6, and 7

Description: It was the implementation of planning stage. It was comprised of a series of activities conducted by the research subject herself. Here, the researchers acted as observers.

3. Observing

Time: Cycle $1 \& 2$ : Meeting 3, 4, 5, 6, and 7

Description: It was conducted when the acting stage was running. It aimed to collect the data and information about the learning process. 
Soerjowardhana, A. \& Nugroho, R.A., Developing English Job Interview Skill 185 by SALL through Audio Podcast Based Learning Media

\section{4. $\quad$ Reflecting}

Time: Cycle $1 \&$ 2: Meeting 8

Description: In this stage, the researchers conducted an oral test. It aimed to analyze, examine, evaluate, and conclude the result of the observing stage. Its results served as the basis for improving the learning process within the next cycle.

\section{RESULTS}

This section contains the results of cycle one and two of the AR. Thus, the section's presentation follows four stages: planning, acting, observing, and reflecting.

1. Cycle 1

a) Planning

In this stage, the researchers designed an English job interview simulation with the subject of research as the interviewee. The researchers developed several questions based on five topics of interview. The greatest problems for the research subject were the inability to develop appropriate answers and to comprehend interviewer's questions. This incapability lessened her confidence to speak. Furthermore, based on the answers, the researchers identified research subject's answer pattern. The pattern can be seen in figure 2 .

In figure 2, the researchers identified three answer types. The highest finding was the type of answer showing inexperienced personality. This type of answer could be found in all five interview topics asked to the subject of research. One of the examples was answering the question "what do you need from working here?" with "I need an experience". The question belongs to professional motivation question. It functions to identify the interviewee's inner motivation. However, the answer blatantly emphasized her lack of experience in working context. It occurred because the research subject felt that she had nothing to offer due to her being fresh graduate. However, in the real English interview setting, most employers seek for a prospective employee who is able to cope with demanding task. This ability can be shown by either fresh 
186 Celt: A Journal of Culture, English Language Teaching \& Literature, Volume 17, Number 2, December 2017, pp. 178 - 195

graduate or experienced person. In order to express this ability, normative answers must be avoided.

Figure 2:

Answer pattern

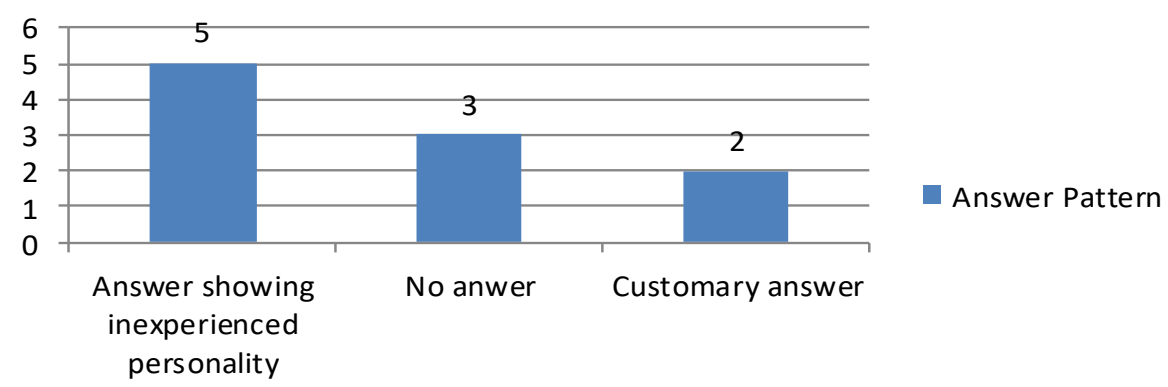

The next problem occurred was the no answer. This type of answer was identified in three interview topics, namely personality assessment, professional motivation, and career development. Here, the research subject expressed her inability to understand interviewer's questions by using standard formulaic expression, such as "I don't know the answer" or by paralinguistic gestures, head shake, for instance. This manifestation must be heavily avoided by interviewees should they want to succeed in an interview.

Lastly, the research subject also dealt with customary answers during the interview simulation. This type of answer occurred in two interview topics, namely personality assessment and career development. Customary answers are:

(i) Simple answers that highlight the inability to develop answers, for example answering the question "how good are you in this field?" with "very good". In order to impress employers, developing answer appropriately is highly recommended. This kind of question is in reality not a close-end question, therefore a detailed answer pertaining to interviewee's strength must have been shown to the interviewer.

(ii) Answers that only express familiar surroundings, for example answering "what is your biggest weakness?" with "I am afraid of dark place and spiders". This answer is not a professional answer. It reflects a shallow understanding to the question asked. This question intends to explore interviewee's personality 
Soerjowardhana, A. \& Nugroho, R.A., Developing English Job Interview Skill 187 by SALL through Audio Podcast Based Learning Media

and its relationship to future work. Thus, it must be answered by explaining interviewee's limitations in working context and ways to overcome them.

From this observation, the researchers were able to identify English interview problems faced by the research subject. These findings served as the basis to develop SALL through audio-podcast based learning media.

\section{b) Acting and Observing}

Based on the result of planning stage, the researchers developed an audio-podcast based learning media that contained deliberate answer structures. The answers for the interview about the personality assessment are structured as follows:

Table 3:

\section{Answers for Personality Assessment}

\begin{tabular}{ll}
\hline Question*: "What do you have to offer?" (sample question, questions were varied) \\
\hline Condition & Although I am a fresh graduate, \\
\hline Strength & I have the ability to adapt to the environment quickly. \\
\hline Real example & For example, I was the youngest head of student board. \\
\hline Modesty & $\begin{array}{l}\text { However, to push myself forward, I need to work at a bigger company } \\
\text { like yours. }\end{array}$ \\
\hline
\end{tabular}

The answers for the interview about the professional motivation are structured as follows:

\section{Table 4:}

\section{Answers for Professional Motivation}

\begin{tabular}{|c|c|}
\hline \multicolumn{2}{|c|}{ Question*: "How much salary do you want?" } \\
\hline Strength & I believe I have the capacity to achieve the targets. \\
\hline Modesty & I have not only the ability, but also the company that supports me. \\
\hline Real example & $\begin{array}{l}\text { I think } 5 \text { million Rupiah will not be that much to hire potential } \\
\text { candidate. }\end{array}$ \\
\hline Consequence & $\begin{array}{l}\text { I will be } 100 \% \text { committed to all targets set by the company. If I fail } \\
\text { to achieve them, I will also be committed to all consequences. }\end{array}$ \\
\hline
\end{tabular}


188 Celt: A Journal of Culture, English Language Teaching \& Literature, Volume 17, Number 2, December 2017, pp. 178 - 195

The answers for the interview, which assess the career development are structured as follows:

Table 5:

Answers for Career Development

\begin{tabular}{ll}
\hline Question*: "What are your major accomplishments in your career to date?" \\
\hline Condition & I know that I am still a fresh graduate. \\
\hline Strength & $\begin{array}{l}\text { But, I started gaining experiences as a community member and } \\
\text { student representative at the earliest of time. }\end{array}$ \\
\hline Justification & $\begin{array}{l}\text { I need to gain them because I am sure that I will compete with } \\
\text { millions of job seekers. I have to be different. I have to develop my } \\
\text { leadership and independence as early as possible. }\end{array}$ \\
\hline Real example & $\begin{array}{l}\text { And it finally loomed. I was the youngest head of student board } \\
\text { being elected. Moreover, I was also the head of youth association in } \\
\text { my neighborhood. Organizing hundreds of youth was not an easy } \\
\text { task. It needed leadership skill and perseverance. }\end{array}$ \\
\hline Modesty & $\begin{array}{l}\text { However, I realize that these accomplishments are nothing without } \\
\text { faith shown by lovely people around me. And I believe, this company } \\
\text { has excellent support system that can trigger someone's potential. }\end{array}$
\end{tabular}

The answers for the interview, which assess the working experience is structured as follows:

Table 6:

\section{Answers for Working Experience}

Question*: "How long have you been seeking work?"

Condition

As a graduate from reputable university, the pressure of quickly being hired is high.

Strength

But, I am confident that I have the strengths I already told you.

Real example

As soon as I found the announcement two weeks ago,

Modesty

I am sure that I am not going to miss a chance working in one of the biggest companies in Indonesia. 
Soerjowardhana, A. \& Nugroho, R.A., Developing English Job Interview Skill 189 by SALL through Audio Podcast Based Learning Media

The answers for the interview, which assess the knowledge about the employer are structured as follows:

\section{Table 7:}

\section{Answers for the Knowledge about the Employer}

\begin{tabular}{|c|c|}
\hline \multicolumn{2}{|c|}{ Question*: "Why do you want this job?" } \\
\hline Strength & $\begin{array}{l}\text { I am a social butterfly with high determination. I know that this job } \\
\text { highly requires that attributes. }\end{array}$ \\
\hline Contribution & $\begin{array}{l}\text { With the attributes, I will be able to attract more connections to the } \\
\text { company. }\end{array}$ \\
\hline Modesty & I realize this company's image can attract connections easily. \\
\hline Contribution & $\begin{array}{l}\text { But, I will also do my best to maintain and improve the connections } \\
\text { that have already been made. }\end{array}$ \\
\hline
\end{tabular}

Based on the answers as structured above, the research subject was then asked to learn independently through audio-podcast based learning media. She was instructed to learn the answer structure and important keywords. The key words that need to be kept in her mind include words expressing professionalism (attributes, determination, potential, etc.), conjunctions (moreover, but, etc.), and collocations (support system, social butterfly, etc.). The research subject realized and evaluated her initial inaccuracies after the introduction of SALL and audio-podcast learning media. She was eager to improve all of the mistakes by using SALL through audio-podcast based learning media.

\section{c) Reflecting}

In this stage, the researchers conducted an oral test. After that, we brought together data from the result of English interview simulation in the planning stage, observation, and oral test result. Based on the collected data in the first cycle (planning, acting, and observing stages), the research subject had these attributes:

Table 8:

The Attributes of Research Subject in Cycle 1

\begin{tabular}{ll}
\hline Level & Description \\
\hline \multicolumn{1}{l}{ ENGLISH INTERVIEW SIMULATION (EIS) } \\
\hline Function & $\begin{array}{l}\text { Creates with language and maintains simple conversations, asks and } \\
\text { answers questions, can get into, through and out of simple social }\end{array}$ \\
\hline
\end{tabular}


190 Celt: A Journal of Culture, English Language Teaching \& Literature, Volume 17, Number 2, December 2017, pp. 178 - 195

and/or transactional situations

Intermediate 1. Everyday topics, such as self, home, family, interests, and leisure Content or recreation

2. Daily routine, familiar surroundings

3. Routine travel needs

\section{ACTING-OBSERVING STAGE (AOS)}

Intermediate Creates with language and maintains simple conversations, asks and Function answers questions, can get into, through and out of simple social and/or transactional situations

Advanced Concrete topics going beyond self and community, family, extending Content to work, community, and current events

Based on the result of EIS in the planning stage, research subject's level was of intermediate function and content. But, during the AOS, the researchers identified that she improved her answers and reduced customary answers. This proved that by following the answer structures, the subject of research succeeded to develop ideas and increased her content level into advanced. Meanwhile, the oral test result (OTR), as shown by Figure 3 in Cycle One has some minor differences. The answers, which show inexperienced personality and no answer still occurred:

Figure 3:

OTR in Cycle 1

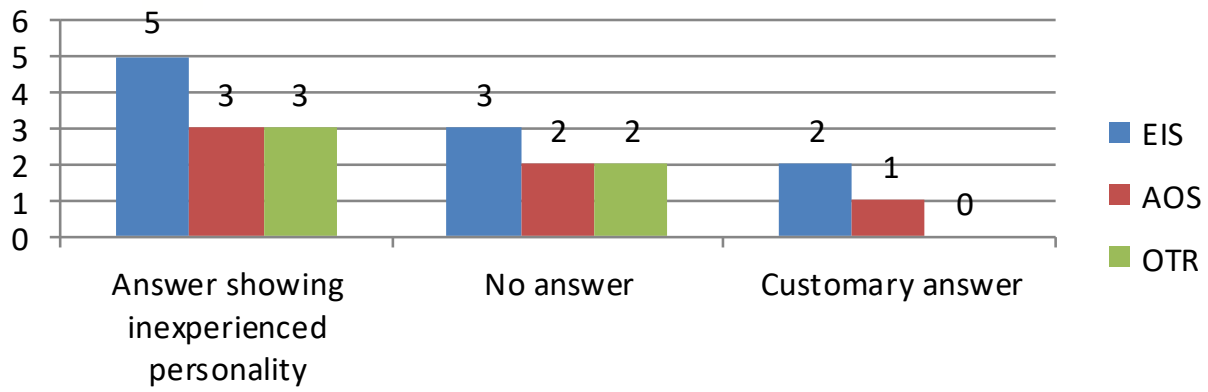

The former took place in three interview topics and the latter in two topics. Only customary answer could be completely abandoned by the research subject. This result was brought as suggestion for cycle 2 . 


\section{Cycle 2}

Just like Cycle 1, Cycle 2 also has three stages to go through, i.e. planning, acting and observing; and reflecting.

\section{a) Planning}

From the result of reflecting stage in cycle One, the aims of cycle Two were to eliminate answer showing inexperienced personality and no answer. To achieve them, the research subject was advised to develop her listening skill and vocabulary, particularly on words expressing professionalism, conjunctions, and collocations. Therefore, the sound adjustment and material addition on the audio podcast were unavoidable. The quality of podcast itself was made better through the addition of stereo recording, speed rate adjuster panel, and answer samples.

\section{b) Acting and Observing}

The subject of research spent five meetings in cycle Two to improve her vocabulary mastery and listening skill. She enjoyed the new format of audio podcast. She said that the new format enabled her to self-correct each interview practiced. The learning was focused on three interview topics that needed improvement, namely personality assessment, professional motivation, and career development. In the second cycle, the research subject learnt the materials for Personality Assessment and Motivation as follows:

\section{Table 9:}

\section{Key Words for Personality Assessment}

Question*: "What do you have to offer?"

Condition Fresh graduate, minimum working experience

Strength Discipline, enthusiastic, young spirit

Real example Head of youth organization, cum laude, seminar participant

Modesty Guidance, good support system, best company

Table 10:

Key Words for Personal Motivation

Question*: "How much salary do you want?"

Strength Capacity, target oriented 
192 Celt: A Journal of Culture, English Language Teaching \& Literature, Volume 17, Number 2, December 2017, pp. 178 - 195

\begin{tabular}{ll}
\hline Modesty & Company support, trusted company \\
\hline Real example & 5 million Rupiah \\
\hline Consequence & Consequence, penalty, reward \\
\hline
\end{tabular}

Wheras, the materials for Career Development are as follows:

\section{Table 11: \\ Key Words for Career Development}

\begin{tabular}{ll}
\hline Question*: "What are your major accomplishments in your career to date?" \\
\hline Condition & A graduate from reputable university, the oldest child, challenge \\
\hline Strength & Leadership, character, responsibility, fair \\
\hline Justification & $\begin{array}{l}\text { Oldest child } \rightarrow \text { responsibility, a graduate from reputable universit) } \\
\rightarrow \text { challenge }\end{array}$ \\
\hline Real example & Head of organization, member of sporting club \\
\hline Modesty & Direction, supervision, acknowledged company \\
\hline
\end{tabular}

The researchers were able to identify that the research subject recognized the importance of learning the structure and key words of each topic. She was certain and convinced that SALL through audio podcast-based learning media helped improve her English interview skill.

\section{c) Reflecting}

In the last stage of cycle 2, again, the researchers conducted an oral test to the research subject. It aimed to identify the improvement she made. Based on the OTR of cycle 2, the subject of research successfully eliminated all the negative remarks in Cycle 1 . She did not produce answer showing inexperienced personality and no answer in the oral test. To support this claim, below is the transcription of her oral test taken from the Personality Assessment topic.

Table 12:

Oral Test for Personality Assessment

\begin{tabular}{ll}
\hline Question*: "How do others describe you?" \\
\hline Condition & 1. As a recent graduate from reputable university, \\
\cline { 2 - 2 } & 2. I am also still young, \\
\hline
\end{tabular}


Strength

1. People see me as a competitive person. To enter the university was hard. To graduate from was harder.

2. I am like a sponge, I can absorb and study many things witk enthusiasm

Real example I was an active follower of many motivation and education seminars. I was also trusted by my lecturer to be his lab assistant.

Modesty However, to uplift my real potential, I still need guidance from outstanding figures who I massively found in your company.

The subject of research revealed that the interview answers were developed from the key words she had learned before. Based on the collected data in the oral test, the research subject had these attributes:

Table 13:

The Attributes of Research Subject in Cycle 2

\begin{tabular}{ll}
\hline Level & Description \\
\hline \hline Advanced & Can get into, through and out of situations with a complication \\
Function & $\begin{array}{l}\text { narrates, describes, explains, compares, and discusses in past } \\
\text { present, and future time/major aspect frames }\end{array}$ \\
\hline $\begin{array}{l}\text { Advanced } \\
\text { Content }\end{array}$ & Concrete topics going beyond self and community, family, extendinধ \\
\hline
\end{tabular}

Initially, the research subject's level was of intermediate function and content. After she used SALL through audio podcast-based learning media in Cycle 1, she improved her content level into advanced one, while her function level was still the same. However, in Cycle 2, she increased her function and content level into advanced ones. This increase happened because she made a shift of function and content of interview answers. From the function point of view, initially, the research subject used descriptive answers to answer the questions. These answers were not well-developed. The subject of research never explained, compared, or discussed any major aspect frames in her answers. After she learned about the interview structures and key words, in the last oral test in Cycle 2, she finally managed to use narrative answers which highlighted the use of explanation, comparison, and discussion in past, present, and future. From the content point of view, the improvement could already be seen in the first cycle. Initially, the research subject used answers that contained substances that were closely related to her life, i.e. 
194 Celt: A Journal of Culture, English Language Teaching \& Literature, Volume 17, Number 2, December 2017, pp. 178 - 195

everyday topics and daily routines. After she used SALL through audio podcast-based learning media in Cycle 1, she instantly improved her content level into advanced one. It seemed that the ability to improve content lied on the mastery of vocabulary indicating professional context rather than the answer structures. Apart from that, the researchers found a positive result in this study. SALL through audio podcast-based learning media made a direct impact to the improvement of English job interview skill.

\section{CONCLUSION}

The result shows that after two treatments, the research subject (interviewee/job seeker) improves her English job interview skill. The improvement can be seen from: (1) the changes according to the functional ability, it is shown from the change of answer style from descriptive into narrative way; and (2) the changes according to the content, it is shown from the change of answer content from daily routine into professional rational. It can be identified that there is a direct correlation between the use of SALL through audio podcast-based learning media and English job interview skill improvement. Therefore, the researchers recommend the Indonesian job seekers to use audio podcast-based learning media by SALL to develop their English job interview skill.

\section{ACKNOWLEDGEMENT}

The researchers of this study express sincere gratitude to the Directorate of Research and Community Services (DRPM), Ministry of Research and Higher Education. This article is the research result funded by the Directorate under Hibah Penelitian Dosen Pemula (PDP) research scheme 2017 and has been disseminated in ICLT conference at Grand Candi Hotel on September 14, 2017.

\section{REFERENCES}

Herrera Díaz, L. E. (2012). Self-access language learning: Students' perceptions of and experiences within this new mode of learning. Profile Issues in 
Soerjowardhana, A. \& Nugroho, R.A., Developing English Job Interview Skill 195 by SALL through Audio Podcast Based Learning Media

Teachers Professional Development, 14(1), 113-127. Retrieved from http://files.eric.ed.gov/fulltext/EJ1051651.pdf

https://www.ets.org/toefl_itp/research/performance-descriptors/

Podcast. (n.d.). Merriam-Webster Online. In Merriam-Webster. Retrieved from https://www.merriam-webster.com/dictionary/podcast.

McTaggart, R., \& Kemmis, S. (Eds.). (1988). The action research planner.

Melbourne: Deakin University.

Overseas Programming and Training Support (OPATS) Peace Corps. (2005).

Language Proficiency Interview: Manual for Testers. Washington D.C.:

Peace Corps Information Collection and Exchange Publication No. T0130. Retrieved from https://fsi-languages.yojik.eu/languages/ PeaceCorps/EnglishTEFL/T0130_English_LPI.pdf

Varasarin, P. (2007). An action research study of pronunciation training, language learning strategies and speaking confidence (Doctoral dissertation, Victoria University). Retrieved from vuir.vu.edu.au/1437/1/Varasarin.pdf

Zuber-Skerritt, O. (1992). Action Research in Higher Education: Examples and Reflections. London: Kogan Page Limited. 